\title{
Identifikasi Area Prospek Panas Bumi Menggunakan Integrasi Citra Landsat 8 OLI/TIRS dan DEM : Studi Kasus Batu Bini, Kalimantan Selatan \\ Rizki Fadhilah Ramadhan, Rizal Azhari Saputra \\ Universitas Pertamina, DKI Jakarta
}

\author{
INFORMASI NASKAH \\ Diterima: 21 Agustus 2021 \\ Direvisi: 14 September 2021 \\ Disetujui: 29 September \\ 2021
}

Terbit: 30 September 2021

Email korespondensi:

fadhilahrizki867@gmail. com

Laman daring:

https://doi.org/10.37525/

$\mathrm{sp} / 2021-2 / 294$

\begin{abstract}
ABSTRAK
Energi terbarukan adalah pilihan yang tepat untuk menggantikan energi fosil dalam pembangunan berkelanjutan seperti energi panas bumi. Menurut data dari Badan Geologi pada tahun 2019 Indonesia memiliki potensi panas bumi sebesar 23,9 GW. Kegiatan eksplorasi panas bumi di Indonesia telah banyak dilakukan, tetapi eksplorasi tersebut tentunya membutuhkan biaya yang besar, dan memakan waktu yang sangat lama. Oleh karena itu, perlu dilakukan survei komprehensif menggunakan aplikasi penginderaan jauh untuk memetakan daerah yang memiliki potensi panas bumi, Metode penginderaan jauh menjadi alternatif dalam mempermudah tantangan eksplorasi yakni dari segi efektivitas waktu, keekonomisan dan aksesibilitas terhadap lokasi eksplorasi. Salah satu potensi tersebut terletak di Batu Bini, Kalimantan Selatan yang memiliki sistem panas bumi non-vulkanik, ditandai adanya manifestasi berupa mata air panas, keberadaan manifestasi ini dapat berasosiasi dengan struktur geologi yang membentuk zona permeabel.
\end{abstract}

Penelitian ini bertujuan untuk menentukan area prospek panas bumi dengan menggunakan analisis citra satelit Landsat 8 OLI dan diintegrasikan terhadap data DEM. Pengolahan data citra satelit dilakukan agar dapat menafsirkan pola kelurusan dan unit geomorfologi secara visual. Diperlukan penerapan Normalized Difference Vegetation Index (NDVI) untuk memetakan pola sebaran kerapatan vegetasi dan Land Surface Temperature (LST) untuk mengetahui pola sebaran suhu permukaan, kedua analisis tersebut kemudian diintergrasikan dengan analisis Fault Fracture Density (FFD). Hasil integrasi tersebut berupa area seluas $101 \mathrm{~km} 2$ yang mempunyai prospek panas bumi 
dengan parameter zona densitas struktur berkisar 1079-2860 m/km2, manifestasi panas bumi, kerapatan vegetasi sedang-tinggi dan suhu permukaan $20-26^{\circ} \mathrm{C}$. Hasil penelitian ini diharapkan dapat menjadi salah satu metode yang digunakan dalam pengembangan eksplorasi panas bumi dan menjadi acuan untuk eksplorasi lanjut.

Kata kunci: Panas bumi, non-vulkanik, penginderaan jauh, Batu Bini, Landsat 8 OLI

\section{PENDAHULUAN}

Seiring meningkatnya pertumbuhan penduduk Indonesia dari tahun ketahun kemungkinan akan berdampak terhadap penggunaan energi untuk menunjang kebutuhan sehari-hari (Pusat Data Dan Teknologi Informasi ESDM, 2017). Energi terbarukan adalah pilihan yang tepat untuk menggantikan energi fosil dalam pembangunan berkelanjutan seperti energi panas bumi. Berdasarkan kondisi geografis, negara Indonesia berada pada pertemuan antar tiga lempeng tektonik aktif yaitu lempeng Indo-Australia, lempeng Eurasia, dan lempeng Pasifik, berkaitan hal tersebut Indonesia mempunyai potensi panas bumi dimana panas bumi tersebut kemungkinan terjadi dari dalam bumi yang ditransfer melalui sistem rekahan (Manyoe et al., 2015). Menurut data dari Badan Geologi pada tahun 2019 Indonesia memiliki potensi panas bumi sebesar 23,9 GW.

Meski kegiatan eksplorasi panas bumi telah mulai banyak dilakukan di Indonesia, tetapi eksplorasi panas bumi tentunya membutuhkan biaya yang besar, dan memakan waktu yang sangat lama. Oleh karena itu, perlu dilakukan survei komprehensif menggunakan aplikasi penginderaan jauh untuk memetakan daerah yang memiliki potensi panas bumi. Secara pengertian, metode penginderaan jauh merupakan suatu teknologi untuk mendapatkan suatu informasi objek dan sebagainya tanpa melakukan sesuatu atau menyentuhnya secara langsung (Lilliesand et al.,2004). Metode penginderaan jauh menjadi alternatif dalam mempermudah tantangan eksplorasi yakni dari segi efektivitas waktu, keekonomisan dan aksebilitas terhadap lokasi eksplorasi.

Salah satu lokasi yang belum dimanfaatkan potensi panas buminya adalah Batu Bini, Kalimantan Selatan yang memiliki Potensi panabumi berupa jenis spekulatif sebesar 20 Mwe (Direktorat Panas Bumi KESDM Indonesa, 2017). Sistem panas bumi di daerah tersebut berupa panas bumi non-vulkanik, ditandai adanya manifestasi berupa mata air panas, keberadaan manifestasi ini dapat berasosiasi dengan struktur geologi yang membentuk zona permeabel.

Rumusan masalah pada penelitian ini adalah:

1. Apa saja parameter area prospek panas bumi pada area penelitian berdasarkan analisis citra Landsat 8 OLI/TIRS?

2. Bagaimana pengaruh vegetasi, suhu permukaan dan manifestasi terhadap area prospek panas bumi?

3. Bagaimana densitas struktur geologi (sesar dan kelurusan) area penelitian ?

4. Berapa luas area yang memiliki prospek panas bumi pada area penelitian ?

Penelitian ini bertujuan untuk menentukan luasan area prospek panas bumi berdasarkan parameter yang dianalisis menggunakan citra Landsat 8 OLI/TIRS dan pengaruh parameter tersebut dalam penentuan area prospek panas bumi yang diintergrasikan dengan densitas struktur menggunakan data Digital Elevation Model (DEM) terhadap area penelitian. 


\section{TINJAUAN PUSTAKA}

\section{1) Geologi Area Penelitian}

Berdasarkan peta geologi Lembar Amuntai, geologi area penelitian terdiri dari beberapa Formasi batuan, diantaranya berupa : Endapan Aluvium (Qa), berumur Holosen, terusun atas lempung kaolinit dan lanau sisipan pasir, gambut, kerakal, bongkahan lepas; Formasi Dahor (TQd), berumur Plio-Plistosen, tersusun atas batupasir kuarsa berbutir sedang dan terpilah buruk, konglomerat lepas, batulempung, dijumpai lignit dan limonit; Formasi Warukin (Tmw), berumur Miosen Tengah-Miosen Akhir, tersusun atas batupasir kuarsa dan batu lempung dengan sisipan batu bara; Formasi Berai (Tomb), berumur Oligosen-Miosen Awal, tersusun atas batugamping yang mengandung fosil foraminifera besar, Formasi Tanjung (Tet), berumur Eosen, tersusun atas batupasir kuarsa dan batulempung dengan sisipan batubara, beberapa tempat bersisipan batugamping; Formasi Pitap (Ksp), berumur Kapur Akhir, tersusun atas batulanau kersikan, batupasir kersikan dan konglomerat, komponen granit dan batugamping yang dikandungnya; Batuan Gunung Api Haruyan (Kvh), berumur Kapur akhir, tersusun atas breksi dan lava basal, berkedudukan menjemari dengan Formasi Pitap; Granit Belawayan (Kgr), berumur Kapur Awal, tersusun atas granit gabungan dengan granidiorit dan diorit.

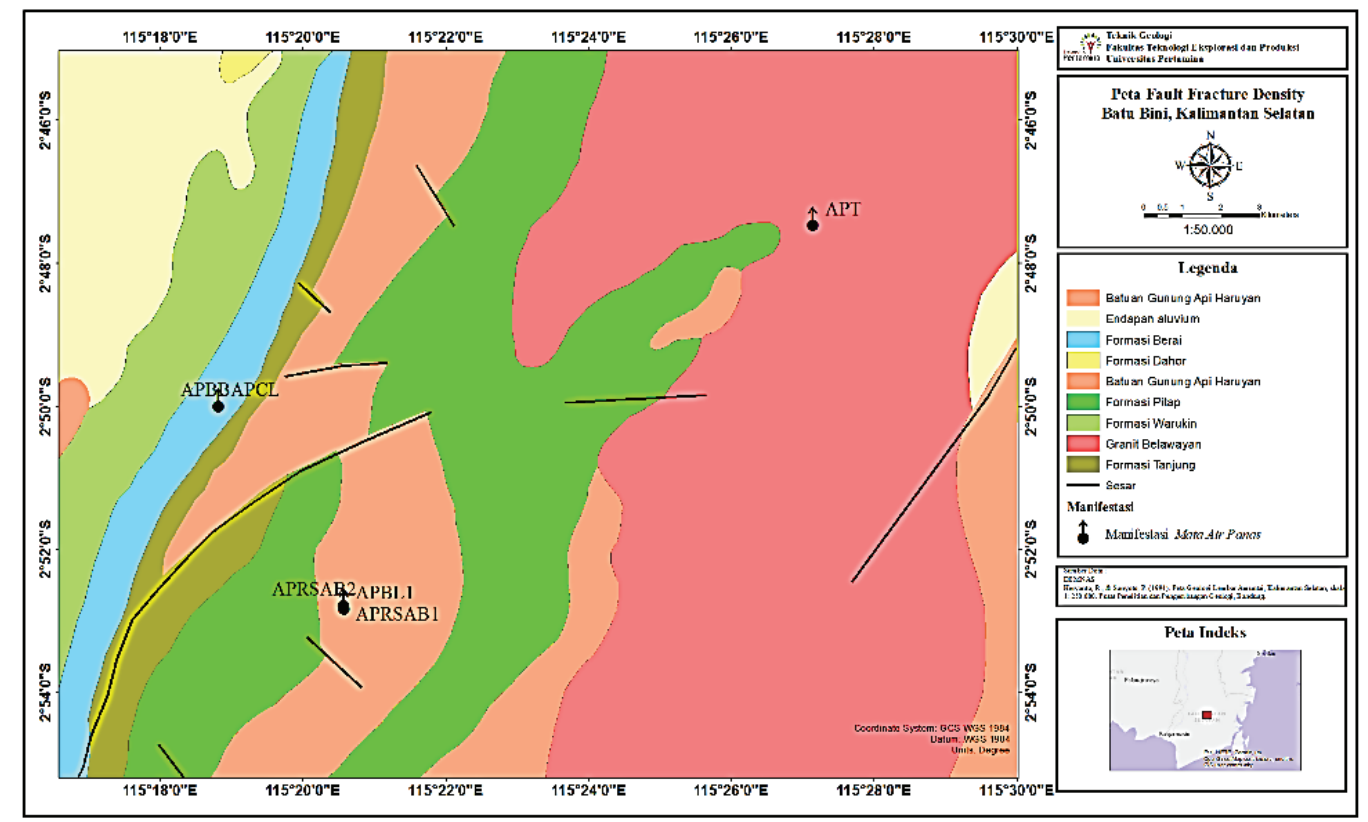

Gambar 1. Geologi Area Penelitian (dimodifikasi dari Heryanto, R., \& Satyoto, P., 1994).

\section{2) Sistem Panas Bumi Batu Bini}

Sistem panas bumi Batu Bini termasuk sistem panas bumi non-vulkanik yang dicirikan oleh adanya manifestasi berupa mata air panas. Sistem ini biasanya memiliki sumber panas yang datang dari intrusi magma tetapi tidak melakukan aktivitas vulkanik (Ramadhan et al, 2021). Sistem inilah yang mencirikan sistem panas bumi di Kalimantan Selatan, khususnya daerah Batu Bini. Sistem panas bumi non-vulkanik secara umum, membentuk suhu reservoir rendah yang mencapai $200^{\circ} \mathrm{C}$ (Kasbani, 2009). Sistem panas bumi tersebut terdapat batasan yang diasumsikan, yakni: a) sistem panas bumi tersebut tidak berhubungan dengan vulkanisme kuarter; b) terdapat di lingkungan sedimen, plutonik, dan metamorf; c) berhubungan dengan 
tektonik; d) manifestasi panas bumi yang secara umumnya ditandai dengan mata air panas (Kasbani, 2009).

\section{3)Parameter Area Prospek Panas Bumi}

Parameter yang penentuan area prospek pada lapangan panas bumi ditandai oleh adanya kehadiran manifestasi berupa mata air panas, manifestasi panas bumi muncul akibat adanya perambatan panas dari bawah permukaan atau adanya rekahan yang dapat mengalirkan fluida ke permukaan (Sukendar, 2016). Keberadaan rekahan tersebut dapat mengindikasikan nilai densitas struktur pada area penelitian.

Parameter area prospek panas bumi dapat ditentukan menggunakan metode penginderaan jauh berupa analisis Normalized Difference Vegetation Index (NDVI), Land Surface Temperature (LST) dan analisis Fault Fracture Density (FFD). Ketiga parameter tersebut dapat menentukan area prospek panas bumi berdasarkan nilai LST disertai dengan pengaruh NDVI yang dapat mempengaruhi hasil analisis suhu permukaan, dan tingkat nilai densitas yang mengindikasikan zona lemah (permeabel) dalam mengalirkan fluida dari reservoir ke permukaan (Utami et al., 2019).

\section{4.) Citra Landsat 8 OLI/TIRS dan Digital Elevation Model}

Dalam melakukan penentuan area prospek panas bumi ada beberapa metode yang bisa digunakan salah satunya adalah menggunakan metode penginderaan jauh berupa Landsat $8 \mathrm{OLI} /$ TIRS. Analisis menggunakan landsat digunakan untuk menentukan kondisi permukaan bumi dengan parameter berupa karakter reflektasni dan adsorpsi gelombang elektromagnetik dari objek di permukaan bumi (Sabins, 1999). Landsat 8 OLI/TIRS digunakan untuk menganalisis sebaran nilai NDVI yang bertujuan untuk tingkat kerapatan vegetasi dan LST untuk memetakan sebaran suhu permukaan.

Data Digital Elevation Model (DEM) merupakan data spasial yang menggambarkan topografi dan relief permukaan suatu daerah. Aplikasi DEM pada eksplorasi panas bumi digunakan untuk visualisasi topografi, struktur geologi (Mboin, I., \& Yator, 2012). DEM juga dapat digunakan untuk menganalisis sebaran nilai densitas struktur permukaan dengan mendelineasi fitur struktur geologi pada permukaan bumi.

\section{METODE PENELITIAN}

Metode yang digunakan pada penelitian ini diawali oleh studi literatur, kemudian dilakukan tahap pengolahan data. Data yang digunakan dalam penelitian ini merupakan data citra satelit Landsat 8 yang diperoleh dari USGS (USGS-EROS) pada path 117 dan row 062. Data citra satelit tersebut direkam pada tanggal 22 April 2015 dengan waktu pengambilan pukul 02:27:44.

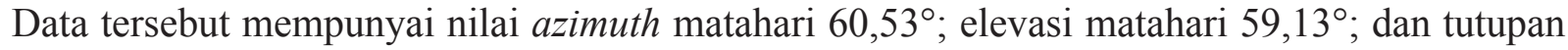
awan berkisar 1,57\%. Selain itu, data yang digunakan berupa data DEM Batu Bini, Kalimantan Selatan, Peta Geologi Lembar Amuntai 1:250.000 oleh Heryanto, R., \& Satyoto, P. (1994).

\section{A. Pre-Processing}

Pada tahap ini dilakukan koreksi radiometrik terhadap data citra satelit Landsat 8 area penelitian. Dilakukannya pengkoreksian tersebut bertujuan untuk memperbaiki dan meminimalisir dari gangguan atmosfer seperti kabut, asap, dan sebagainya pada saat pemrosesan perekaman data citra satelit (Ekadinata et al, 2008). Dalam proses koreksi tersebut, dilakukan pengkalibrasi nilai band yang masih berupa Digital Number (DN) menjadi radian spectral 
(radial TOA), Top of Atmosphere (TOA).

$$
\mathrm{L} \lambda=\mathrm{ML} * \mathrm{QCal}+\mathrm{AL}
$$

Keterangan :

$\mathrm{L} \lambda=$ ToA radiance $($ Watt $/ \mathrm{m} 2$. srad. $\mu \mathrm{m})$.

ML_ = Gain sensor (Radian Multi_Band $x$, dimana $\mathrm{x}$ adalah nomor band (diperoleh dari metadata Landsat 8)).

Qcal = Nilai piksel produk standar (DN) terkuantisasi dan terkalibrasi

$\mathrm{AL}=$ Faktor penskalaan aditif khusus band dari metadata (Radiance_Add_Band_x, dimana $\mathrm{x}$ adalah nomor band (diperoleh dari metadata Landsat 8)).

\section{B. Processing}

Pada tahap ini dilakukan pengolahan data terhadap citra tersebut untuk mendapatkan informasi sebaran nilai NDVI dan LST. Selanjutnya, digunakan data DEM area penelitian untuk dilakukan pengolahan guna mendapatkan sebaran kelurusan di area penelitian melalui metode FFD.

1) Normalized Difference Vegetation Index (NDVI)

Indeks vegetasi merupakan suatu besaran dari nilai kehijauan vegetasi yang diperoleh dari pengolahan sinyal digital data nilai kecerahan dari beberapa band sensor citra satelit (Farras et al, 2017). Dalam proses algoritma NDVI dilakukan perhitungan dengan data Near Infrared dan Red (Sobrino et al, 2008). Hasil ekstraksi dari NDVI tersebut akan menghasilkan rentang nilai antara -1 hingga 1 yang dimana akan merepresentasikan tingkat dari kerapatan vegetasi di suatu daerah. Kalkulasi tersebut dilakukan dengan menggunakan persamaan algoritma sebagai berikut :

$$
\mathrm{NDVI}=\frac{\left(R_{-} N I R_{-}-R_{-} R\right)}{\left(R_{N I R}+R_{R}\right)}
$$

Keterangan :

NDVI $=$ Nilai indeks vegetasi.

RNIR = Radiasi cahaya inframerah dari piksel (band 5).

RR = Radiasi cahaya merah dari piksel (band 4).

Dalam analisis NDVI, digunakan klasifikasi sebagai berikut :

Tabel 1. Tabel Klasifikasi NDVI (Wahyunto, 2006).

\begin{tabular}{|c|c|}
\hline Nilai NDVI & Keterangan \\
\hline$-1<$ NDVI $<-0,03$ & Tak Bervegetasi \\
\hline$-0,03<$ NDVI $<0,15$ & Sangat Rendah \\
\hline $0,15<$ NDVI $<0,25$ & Rendah \\
\hline $0,25<$ NDVI $<0,35$ & Sedang \\
\hline $0,35<$ NDVI $<1$ & Tinggi \\
\hline
\end{tabular}




\section{1) Land Surface Temperature (LST)}

LST merupakan suatu kondisi dari suhu rata-rata permukaan yang dimana tergambarkan dalam cakupan secara piksel dengan kondisi jenis permukaan yang berbeda dan dipengaruhi oleh atmosfer, keseimbangan energi dan sifat termal permukaan, serta bawah permukaan tanah (Faridah \& Krisbiantoro, 2014). Untuk memperoleh nilai sebaran LST pada area penelitian, sebelumnya perlu melakukan kalkulasi NDVI, Proportion of Vegetation (PV), Emisivitas $(\varepsilon)$, Brigtness Temperature (BT).

$$
\mathrm{NDVI}=\frac{\left(R_{-} N I R_{-}-R_{-} R\right)}{\left(R_{N I R}+R_{R}\right)}
$$

Setelah dilakukan pengolahan data dengan kalkulasi NDVI, dilakukan kalkulasi perhitungan PV guna mengetahui kondisi presentasi proyeksi vertikal dari tutupan lahan bervegetasi di area penelitian. Persamaan algoritma yang digunakan sebagai berikut :

$$
\mathrm{PV}=\frac{(\text { NDVI }- \text { NDVImin })}{(\text { NDVImax }- \text { NDVImin })}
$$

Keterangan :

NDVImin = nilai NDVI yang terkecil

NDVImax = nilai NDVI yang tertinggi

PV yang diperoleh tersebut kemudian diperlukan dalam kalkulasi nilai emisivitas $(\varepsilon)$ guna meminimalisir kesalahan dalam mengestimasi kondisi LST dengan data citra satelit Landsat 8 area penelitian. Kalkulasi tersebut dilakukan dengan menggunakan persamaan algoritma sebagai berikut :

$$
\varepsilon=0,004 * \mathrm{PV}+0,986
$$

Keterangan :

$\varepsilon \quad=$ Emisivitas.

$0.004=$ Nilai rata-rata emisivitas berkategori rapat.

$0.986=$ Nilai standar emisivitas lahan terbuka.

Setelah hasil perhitungan emisivitas diperoleh, perlu dilakukan kalkulasi algoritma BT terhadap citra satelit Landsat 8 yang sudah dikoreksi sebelumnya karena sebagai radiasi gelombang elektromagnetik yang dideteksi oleh sensor termal satelit. Kalkulasi tersebut dilakukan dengan menggunakan persamaan algoritma sebagai berikut : 


$$
\mathrm{BT}=\mathrm{K} 2 / \ln (\mathrm{K} 1 / \mathrm{L} \lambda+1)
$$

Keterangan :

BT = Kecerahan temperatur satelit (Kelvin).

$\mathrm{K} 1=$ Konstanta yang terdapat pada metadata band $(\mathrm{W} /(\mathrm{m} 2 . \mathrm{sr} . \mu \mathrm{m})$.

K2 = Konstanta yang terdapat pada metadata band (Kelvin).

$\mathrm{L} \lambda=$ ToA radiance $($ Watt $/ \mathrm{m} 2 . \operatorname{srad} . \mu \mathrm{m})$.

Setelah perhitungan BT kemudian dilakukan perhitungan LST yang dapat diidentifikasikan dari citra landsat 8 yang diesktrak dengan data band 10 dan band 11. Berikut rumusan menghitung LST :

$$
\mathrm{LST}=\frac{\mathrm{BT}}{1+\left(\frac{\lambda \mathrm{BT}}{\mathrm{hc} / \sigma}\right) \ln \varepsilon}-273
$$

Keterangan :

LST $=$ Temperatur suhu permukaan (Celcius).

BT = Kecerahan temperatur satelit (Kelvin).

$\lambda \quad=$ Panjang gelombang radiasi $(11,5 \mu \mathrm{m})$.

$\mathrm{h} \quad=$ Konstanta Planc $(-6,626 * 10-34 \mathrm{Js})$.

c = Kecepatan cahaya $(-2,998 * 108 \mathrm{~m} / \mathrm{s})$.

$\sigma \quad=$ Konstanta Boltzmann $(-1,38 * 1023 \mathrm{~J} / \mathrm{K})$.

$\varepsilon \quad=$ Emisivitas.

$-273=$ Konversi suhu Kelvin ke Celcius 


\section{2) Fault Fracture Density (FFD)}

Fault fracture density adalah metode sederhana yang digunakan untuk menganalisis area kepadatan struktur yang dibentuk oleh interkoneksi sesar dan rekahan (Wibowo, 2010). Metode tersebut dilakukan dengan menganalisis data DEM, data ini digunakan untuk memvisualisasikan garis kelurusan dan struktur geologi berupa sesar di area penelitian, setelah itu data tersebut dianalisis menggunakan metode FFD (Ramadhan et al., 2021). data DEM diekstraksi menjadi hillshade dengan memberikan sudut penyinaran matahari sebesar $0^{\circ}, 45^{\circ}, 90^{\circ}, 135^{\circ}, 180^{\circ}, 225^{\circ}$, $270^{\circ}$, dan $315^{\circ}$ dan ketinggian $45^{\circ}$. Hal ini dilakukan untuk memvisualisasikan semua lereng dan mendapatkan bayangan matahari yang sama (Yanis et al., 2019).

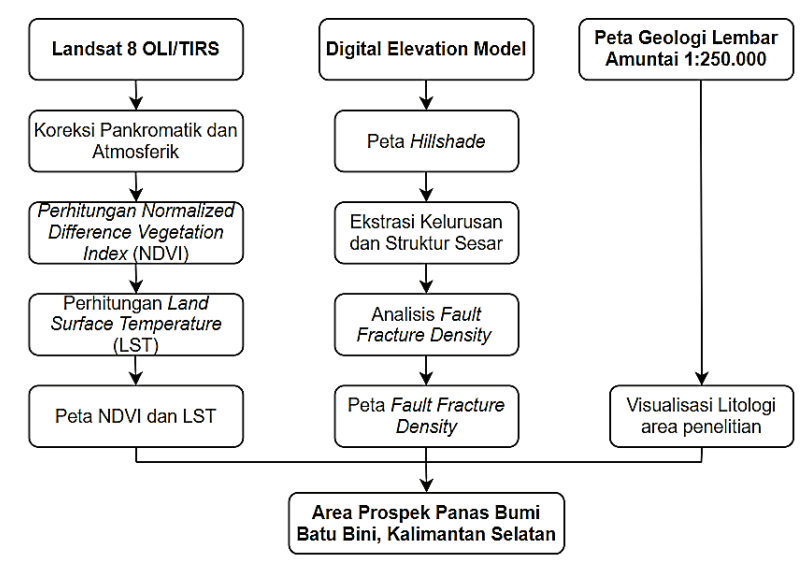

Gambar 2. Diagram Alir Penelitian.

\section{HASIL PENELITIAN DAN PEMBAHASAN}

Berdasarkan analisis yang telah dilakukan, didapatkan hasil berupa peta NDVI, LST dan FFD, hasil ini akan menjadi acuan dalam penentuan area prospek panas bumi di Batu Bini, Kalimantan Selatan.

\section{A. Normalized Difference Vegetation Index (NDVI)}

Dari hasil analisis NDVI terhadap area penelitian, diperoleh nilai rentang NDVI sebesar -0,394 hingga 0,66. Berdasarkan klasifikasi (Wahyunto, 2006), maka tingkat kerapatan dari vegetasi area penelitian didominasi oleh jenis kerapatan vegetasi tinggi, kemudian diikuti oleh tingkat vegetasi, vegetasi sedang, rendah, sangat rendah dan lahan tak bervegetasi. Jika dilihat pada gambar 3, semakin tinggi indeks vegetasi dan mendekati 1, maka semakin rapat vegetasinya.

Berdasarkan peta pada gambar 3. Mata Air Panas Batu Bini (APBB), Crystalline Limestone (APCL), Lokbahan 1 (APLB 1), River Side Altered Breccia 1 (APRSAB), River Side Altered Breccia 2 (APRSAB 2), berada di kawasan jenis vegetasi berupa kerapatan vegetasi yang rapat. Sedangkan mata air panas tanuhi (APT) yang berada di timur laut area penelitian berupa kawasan semak belukar. 


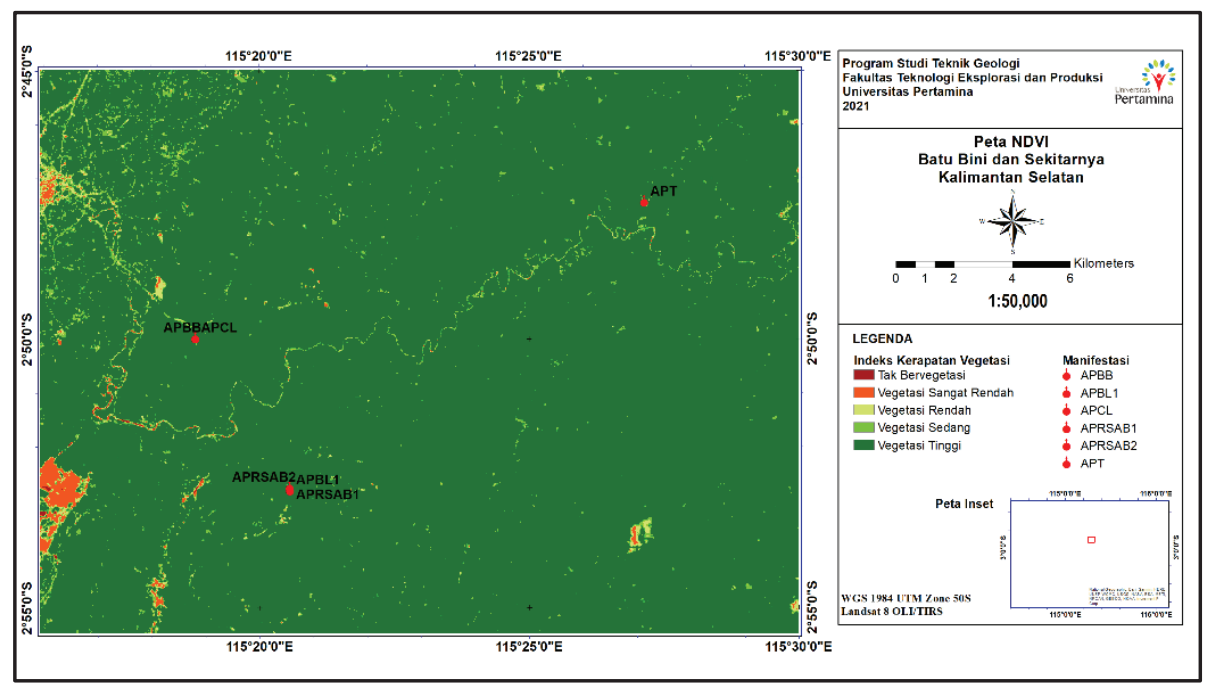

Gambar 3. Peta Normalized Difference Vegetation Index (NDVI).

\section{B. Land Surface Temperature}

Berdasarkan hasil analisis didapatkan bahwa suhu permukaan area penelitian diperoleh nilai minimum yakni $16^{\circ} \mathrm{C}$ dan suhu maksimum yakni $27^{\circ} \mathrm{C}$. dengan metode dapat diketahui berupa sebaran suhu permukaan yang terkait dengan manifestasi panas bumi. Pada area penelitian terdapat 6 mata air panas. Berdasarkan Zhang (2012), semakin tinggi suhu permukaan maka semakin besar kemungkinan daerah memiliki potensi panas bumi. Suhu permukaan yang direkam dapat diinterpretasikan sebagai suhu terluar objek (Handayani, 2007). Pada area yang memiliki lahan berupa vegetasi rendah hingga sedang, suhu permukaan merupakan suhu lapisan terluar permukaan tanah, sedangkan area yang memiliki tingkat vegetasi tinggi seperti hutan dapat diinterpretasikan sebagai suhu permukaan tumbuhan (Hakim et al., 2017). Dengan demikian, kerapatan vegetasi dapat mempengaruhi nilai suhu permukaan.

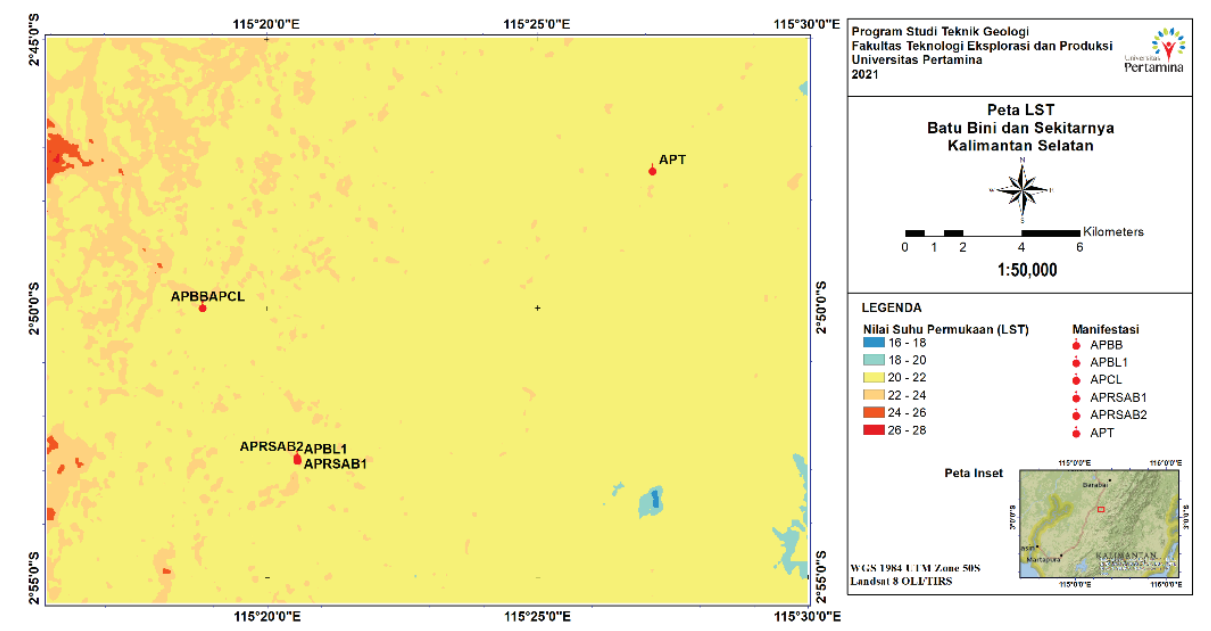

Gambar 4. Peta Land Surface Temperature. 


\section{Hubungan Antara Manifestasi Panas Bumi dan Land Surface Temperature}

Berdasarkan data manifestasi dan LST maka dapat dikaitkan hubungan antara keduanya, hasil analisis menunjukkan bahwa didapatkan pada masing-masing manifestasi memiliki suhu permukaan sebagai berikut:

Tabel 2. Hubungan Suhu Manifestasi dan Suhu Permukaan.

\begin{tabular}{|c|c|c|c|}
\hline No. & Nama & Temperatur Mata Air Panas $\left({ }^{\circ} \mathbf{C}\right)$ & Temperatur Permukaan $\left({ }^{\circ} \mathbf{C}\right)$ \\
\hline 1 & APBB & 39,4 & $22-24$ \\
\hline 2 & APCL & 39 & $22-24$ \\
\hline 3 & APLB 1 & 41,5 & $22-24$ \\
\hline 4 & APRSAB 1 & 42 & $22-24$ \\
\hline 5 & APRSAB 2 & 42 & $22-24$ \\
\hline 6 & APT & 48,8 & $22-24$ \\
\hline
\end{tabular}

Tabel diatas memperlihatkan perbandingan antara temperatur manifestasi mata air panas dengan nilai LST, dimana pada area dengan keberadaan manifestasi memiliki nilai LST yang relatif tinggi berkisar antara $22-24^{\circ} \mathrm{C}$ dibandingkan area sekitarnya. Manifestasi APRSAB 1 , APRSAB 2 dan APT terletak pada vegetasi lebat dan memiliki suhu permukaan yang mendekati suhu permukaan manifestasi APBB, APCL dan APLB 1 yang terletak pada vegetasi sedang. Hal ini jika dikaitkan dengan NDVI yang dapat mempengaruhi nilai LST sehingga nilai LST pada manifestasi yang berada di area vegetasi lebat mendekati nilai LST manifestasi di area dengan vegetasi rendah.

\section{Hubungan antara LST dan NDVI}

Berdasarkan data LST dan NDVI, maka dapat dikorelasikan hubungan antar keduanya, hasil analisis menunjukan bahwa LST dan NDVI memiliki grafik negative linear (regresi) (gambar 5). Pada daerah yang memiliki NDVI tinggi, daerah tersebut memiliki nilai LST yang rendah, semakin rendah nilai NDVI, maka semakin tinggi nilai LST. Hal ini, menunjukkan bahwa semakin tinggi tingkat kerapatan vegetasi di suatu area, maka semakin rendah suhu permukaan (Maharani et al., 2021).

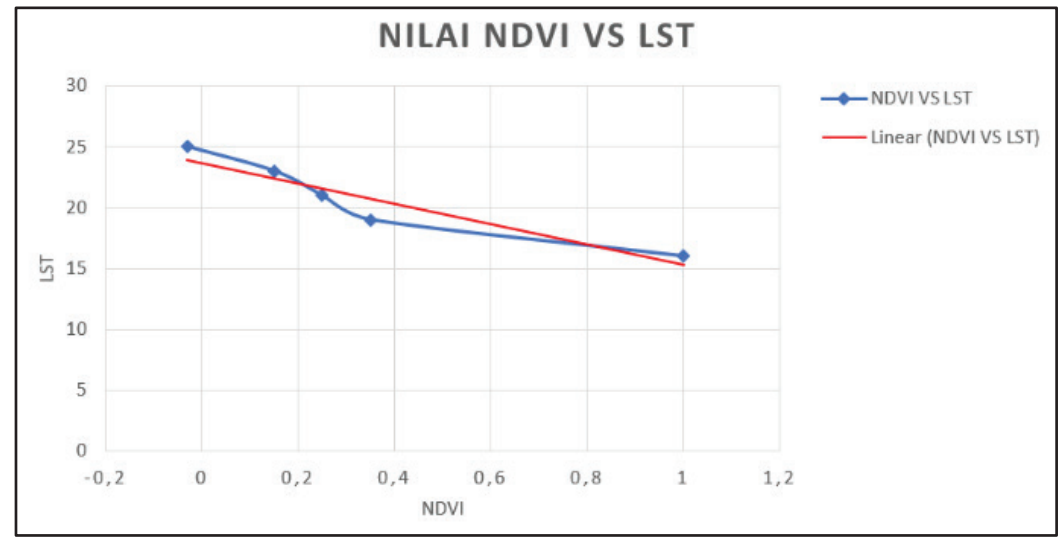

Gambar 5. Grafik Perbandingan NDVI dan LST. 


\section{Fault Fracture Density}

Dalam penelitian ini, sesar dan kelurusan digunakan untuk mengkorelasikan tingkat kerapatan struktur geologi berupa sesar dan kelurusan dengan tingkat densitas dan permeabilitas di area penelitian. Menurut Williams, R. S. (1983), fitur topografi di permukaan bumi yang merepresentasikan zona lemah dapat ditunjukan dengan keberadaan kelurusan. Hasil analisis FFD dapat dilihat peta densitas kerapatan sesar dan kelurusan pada gambar 6. Berdasarkan hasil analisis didapatkan bahwa area penelitian memiliki 3 kelas densitas yakni :

Tabel 3. Tingkat Densitas Area Penelitian.

\begin{tabular}{|c|c|}
\hline Tingkat Densitas & Nilai $\left(\mathbf{m} / \mathbf{k m}^{\mathbf{2}}\right)$ \\
\hline Rendah & 326 \\
\hline Sedang & $1079-1622$ \\
\hline Tinggi & $1622-2860$ \\
\hline
\end{tabular}

Area yang memiliki densitas tinggi berada pada sekitar manifestasi panas bumi, trend sesar pada area ini memiliki orientasi NE-SW dan orientasi kelurusan berarah NW-SE. sesar dan kelurusan tersebut mengontrol densitas pada area penelitian, semakin rapat kelurusan, maka semakin besar nilai densitasnya sehingga menyebabkan semakin besar tingkat permeabilitas suatu area. Kepadatan kelurusan yang dipetakan memberikan informasi tentang zona permeabel di area penelitian untuk menentukan zona terlemah sebagai manifestasi panas bumi (Maharani et al., 2021).

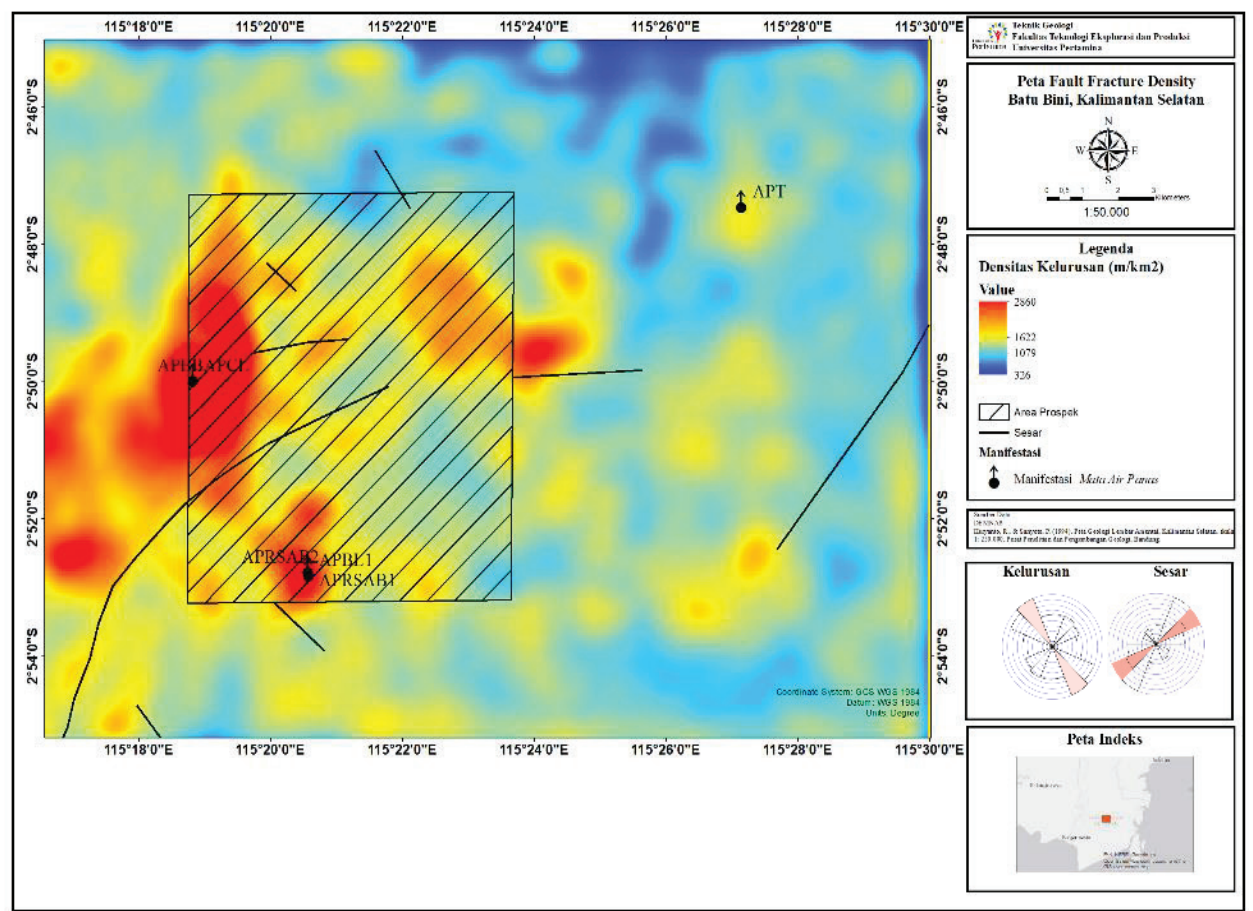

Gambar 6. Peta Fault Fracture Density Batu Bini, Kalimantan Selatan. 
Sesar yang mengontrol permeabilitas pada daerah penelitian antara lain Sesar Batu Bini yang berarah NE-SW, Sesar Hulu Banyu yang memiliki arah N-S, Sesar Tahuni yang berarah NE-SW, Sesar Lokbahan yang berarah NE-SW. Sesar Tahuni dan Sesar Lokbahan diperkirakan sebagai pengontrol hadirnya manifestasi mata air panas Tanuhi dan Lokbahan (Yushantarti et al., 2020).

\section{F. Area Prospek Panas Bumi}

Penentuan area prospek menggunakan parameter berupa densitas struktur, permeabilitas, nilai LST, dan keberadaan manifestasi serta litologi. Area prospek panas bumi dapat dilihat pada gambar 6. Nilai NDVI memiliki korelasi yang baik dengan LST. Area prospek memiliki nilai densitas sedang hingga tinggi dengan rentang nilai densitas $1622-2860 \mathrm{~m} / \mathrm{km}^{2}$, dengan temperatur permukaan pada kisaran $20-26^{\circ} \mathrm{C}$. Area prospek terdiri dari Formasi Gunung Api Haruyan dan Formasi Berai. Manifestasi pada area prospek terdiri dari : mata air panas Batu Bini terletak pada batugamping dan air panas lokbahan terletak pada batubreksi, kedua manifestasi ini dikontrol oleh sesar Batu Bini dan Sesar Lokbahan. Manifestasi mata air panas berada pada area yang memiliki densitas tinggi, hal ini menandakan bahwa terdapat zona lemah yang dapat mengalirkan fluida, pada area ini memiliki nilai permeabilitas yang tinggi. Kelurusan dan sesar mempengaruhi tingkat permeabilitas area prospek, hal ini dikarenakan semakin banyak sesar dan kelurusan maka akan menyebabkan semakin tinggi permeabilitas (Ramadhan et al, 2021).

Area prospek memiliki luas kisaran $101 \mathrm{~km}^{2}$ yang berada pada bagian kiri area penelitian. Berdasarkan data (Direktorat Panas Bumi KESDM Indonesa, 2017), Prospek Batu Bini termasuk kedalam sistem panas bumi non-vulkanik jenis geopressure. Menurut Hochstein \& Browne, P. R (2000), sistem panas bumi jenis geopressure berkaitan dengan bagian dalam pada cekungan sedimen, dimana fluida terperangkap oleh lapisan sedimen permeable yang terendapkan secara cepat. Fluida tersebut dibatasi oleh batuan yang bersifat impermeable yang menyebabkan tekananya menjadi besar. Air panas di bawah tekanan tinggi di akuifer pasir menjadi target utama pengeboran karena mengandung metana terlarut (Lund, 2008).

\section{KESIMPULAN}

Berdasarkan penelitian yang telah dilakukan dapat disimpulkan bahwa parameter area prospek panas bumi menggunakan metode penginderaan jauh pada area penelitian terdiri dari nilai densitas struktur yang dapat mengindikasikan zona lemah (permeabel) pada area penelitian yang dapat memunculkan manifestasi. Nilai NDVI dan LST memiliki korelasi yaitu semakin tinggi kerapatan vegetasi, maka semakin rendah suhu permukaan dan semakin rendah kerapatan vegetasi, maka semakin tinggi suhu permukaan. Korelasi antara suhu manifestasi terhadap LST dipengaruhi oleh kondisi vegetasi yang tinggi pada area penelitian, karena kondisi vegetasi rapat mempengaruhi rekaman suhu permukaan. Suhu permukaan yang tinggi mengindikasikan area tersebut memiliki manifestasi panas bumi. Nilai densitas struktur pada area penelitian didapatkan pada kisaran 326-2860 m/ $\mathrm{km}^{2}$ dan pada area prospek memiliki densitas $1079-2860 \mathrm{~m} / \mathrm{km}^{2}$. Nilai densitas struktur dipengaruhi oleh kepadatan kelurusan dan sesar yang dapat mempengaruhi kondisi permeabilitas suatu area. Hal ini dapat memunculkan manifestasi panas bumi yang dapat mengindikasikan keberadaan reservoir panas bumi. Area prospek memiliki luas $101 \mathrm{~km}^{2}$ atau dengan ditandai oleh adanya beberapa manifestasi berupa mata air panas yang berada pada densitas sedang-tinggi. Semakin tinggi densitas, maka akan semakin tinggi permeabilitas, zona permeabilitas tersebut bisa mengalirkan fluida. Selain itu, area prospek memiliki LST $20-26^{\circ} \mathrm{C}$ dengan kerapatan vegetasi sedang-tinggi. 


\section{DAFTAR PUSTAKA}

Direktorat Panas Bumi Kementerian Energi dan Sumber Daya Mineral Indonesia. (2017). Potensi Panas Bumi Indonesia Jilid 2, Kementerian Energi dan Sumber Daya Mineral, Jakarta.

Ekadinata, A., Dewi, S., Hadi, D., Nugroho, D., \& Johana, F. (2008). Sistem Informasi Geografis Untuk Pengelolaan Bentang Lahan Berbasis Sumber Daya Alam. Bogor, Yudhistira.

Faridah, S. A. N., \& Krisbiantoro, A. (2014). Analisis Distribusi Temperatur Permukaan Tanah Wilayah Potensi Panas Bumi Menggunakan Teknik Penginderaan Jauh di Gunung Lamongan, Tiris-Probolinggo, Jawa Timur. Berkala Fisika, 17(2), 67-72.

Farras, N., Sukmono, A., \& Bashit, N. (2017). Analisis Estimasi Energi Panas Bumi Menggunakan Citra Landsat 8 (Studi Kasus: Kawasan Gunung Telomoyo). Jurnal Geodesi Undip, 6(4), 371-380.

Hakim, L., Ismail, N., \& Faisal, F. (2017). Kajian Awal Penentuan Daerah Prospek Panas Bumi Di Gunung Bur Ni Telong Berdasarkan Analisis Data DEM SRTM dan Citra Landsat 8. Jurnal Rekayasa Elektrika, 13(3), 125-132.

Handayani, N. (2007). Identifikasi Perubahan Kapasitas Panas Kawasan Perkotaan Dengan Menggunakan Citra Landsat TM/ETM+ (Studi Kasus: Kodya Bogor).

Hochstein, M. P., \& Browne, P. R. (2000). Surface Manifestations of Geothermal Systems with Volcanic Heat Sources. Encyclopedia of Volcanoes, 835-855.

Kasbani, K. (2009). Tipe Sistem Panas Bumi di Indonesia dan Estimasi Potensi Energinya. Buletin Sumber Daya Geologi, 4(3), 23-30.

Heryanto, R., \& Sanyoto. P. (1994). Peta geologi lembar Amuntai, Kalimantan: Geological map of the Amuntai Quadrangle, Kalimantan. Bandung: Pusat Penelitian dan Pengembangan Geologi.

Lillesand, T. M., Kiefer, R. W., \& Chipman, J. W. (2004). Concepts And Foundations of Remote Sensing. remote sensing and image interpretation, 1-57.

Lund, J. W. (2008). Development and Utilization of Geothermal Resources. Proceedings of ISES World Congress 2007 Vol. I-V. pp. 87-95. Springer, Berlin, Heidelberg

Maharani, A., Salsanur, V., Hilal, A., \& Aprilian, Y. (2021). Preliminary Interpretation for Geothermal Potential Area Using DEM And Landsat OLI 8 in Mount Endut. Bulletin of Scientific Contribution: Geology, 19(1), 35-46

Manyoe, I.N., Irfan, U.R., dan Suriamiharja, D.A. 2015. Distribusi Anomali Magnetik Daerah Panas Bumi Bongongoayu, Gorontalo. Seminar Ilmiah Nasional Penguatan Kemitraan Berbasis Ipteks Inovasi untuk Kemaslahatan BMI. Fakultas Teknik Universitas Hasanuddin Makassar, Indonesia.

Mboin, Irene \& Yator, Esther (2013). Digital Elevation Models Applications in Menengai Geothermal Field. Geothermal Resources Council Transactions, 37.

Ramadhan, R.F et al. (2021). Effect of The Palu-Koro Fault on The Permeability Distribution of The Geothermal System in Central Sulawesi. PROCEEDINGS, 10th ITB International 
Geothermal Workshop. Bandung Institute of Technology, Bandung, July 26-27 2021

Sabins, F. F. (1999). Remote sensing for mineral exploration. Ore geology reviews, 14(3-4), 157-183.

Sobrino, J. A., Jiménez-Muñoz, J. C., Sòria, G., Romaguera, M., Guanter, L., Moreno, J., ... \& Martínez, P. (2008). Land surface emissivity retrieval from different VNIR and TIR sensors. IEEE transactions on geoscience and remote sensing, 46(2), 316-327.

Sukendar, P.M., Sasmito, B. dan Putra, A.W. (2016). Analisis Sebaran Kawasan Potensial Panas Bumi Gunung Salak Dengan Suhu Permukaan, Indeks Vegetasi dan Geomorfologi. Semarang. Universitas Diponegoro.

Utami, R. B., Sasmito, B., and Bashit, N., 2019. Analisis Rekomendasi Daerah PLTP(Pembangkit Listrik Tenaga Panas Bumi) Menggunakan Sistem Informasi Geografis. Jurnal Geodesi Undip, Volume 8(1), pp. 408-417.

Wahyunto, W. (2006). Pendugaan Produktivitas Tanaman Padi Sawah Melalui Analisis Citra Satelit, Informatika Pertanian. Bogor: Departemen Pertanian

Wibowo, H. H. (2010). Application of Fault and Fracture Density (FFD) Method for Geothermal Exploration in Non-Volcanic Geothermal System; a Case Study in Sulawesi-Indonesia. Jurnal Geoaplika, 5(1), 027-037.

Williams, R. S. (1983) “Geological applications”, In. Colwell, R. N. (eds). "Manual of Remote Sensing”, 1667- 1951. Falls Church, VA: American Society of Photogrammetry.

Yanis, M., Ismail, N., Hermansyah, L. V., Nanda, M., \& Abdullah, F. (2019). Fault Mapping in Weh Island based on Fault Fracture Density Method (FFD). Journal of Aceh Physics Society, $8(1), 6-10$.

Yushantarti, A. (2020). Thermal Fluids Characteristics of Low Temperature Geothermal Systems at Kalimantan Island, Indonesia. PROCEEDINGS, 45th Workshop on Geothermal Reservoir Engineering Stanford University, Stanford, California, February 10-12, 2020

Zhang, G., Dong, J., Xiao, X., Hu, Z., \& Sheldon, S. (2012). Effectiveness of ecological restoration projects in Horqin Sandy Land, China based on SPOT-VGT NDVI data. Ecological Engineering, 38(1), 20-29.

Pusat Data Dan Teknologi Informasi ESDM. (2017). Kajian Penyediaan dan Pemanfaatan Migas, Batubara, EBT Dan Listrik. Pusat Data dan Teknologi Informasi Energi dan Sumber Daya Mineral Kementerian Energi dan Sumber Daya Mineral. Jakarta Barat. 